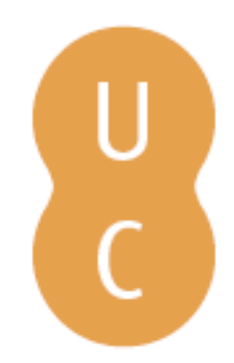

\title{
pommalina
}

\section{Public sector accounting future challenges: EPSAS outlook}

Autor(es): $\quad$ Schmidthuber, Lisa; Hilgers, Dennis

Publicado por: Imprensa da Universidade de Coimbra

URL

persistente: URI:http://hdl.handle.net/10316.2/47459

DOI: $\quad$ DOI:https://doi.org/10.14195/978-989-26-1861-6_14

Accessed : $\quad$ 26-Apr-2023 15:35:28

A navegação consulta e descarregamento dos títulos inseridos nas Bibliotecas Digitais UC Digitalis, UC Pombalina e UC Impactum, pressupõem a aceitação plena e sem reservas dos Termos e Condições de Uso destas Bibliotecas Digitais, disponíveis em https://digitalis.uc.pt/pt-pt/termos.

Conforme exposto nos referidos Termos e Condições de Uso, o descarregamento de títulos de acesso restrito requer uma licença válida de autorização devendo o utilizador aceder ao(s) documento(s) a partir de um endereço de IP da instituição detentora da supramencionada licença.

Ao utilizador é apenas permitido o descarregamento para uso pessoal, pelo que o emprego do(s) título(s) descarregado(s) para outro fim, designadamente comercial, carece de autorização do respetivo autor ou editor da obra.

Na medida em que todas as obras da UC Digitalis se encontram protegidas pelo Código do Direito de Autor e Direitos Conexos e demais legislação aplicável, toda a cópia, parcial ou total, deste documento, nos casos em que é legalmente admitida, deverá conter ou fazer-se acompanhar por este aviso. 

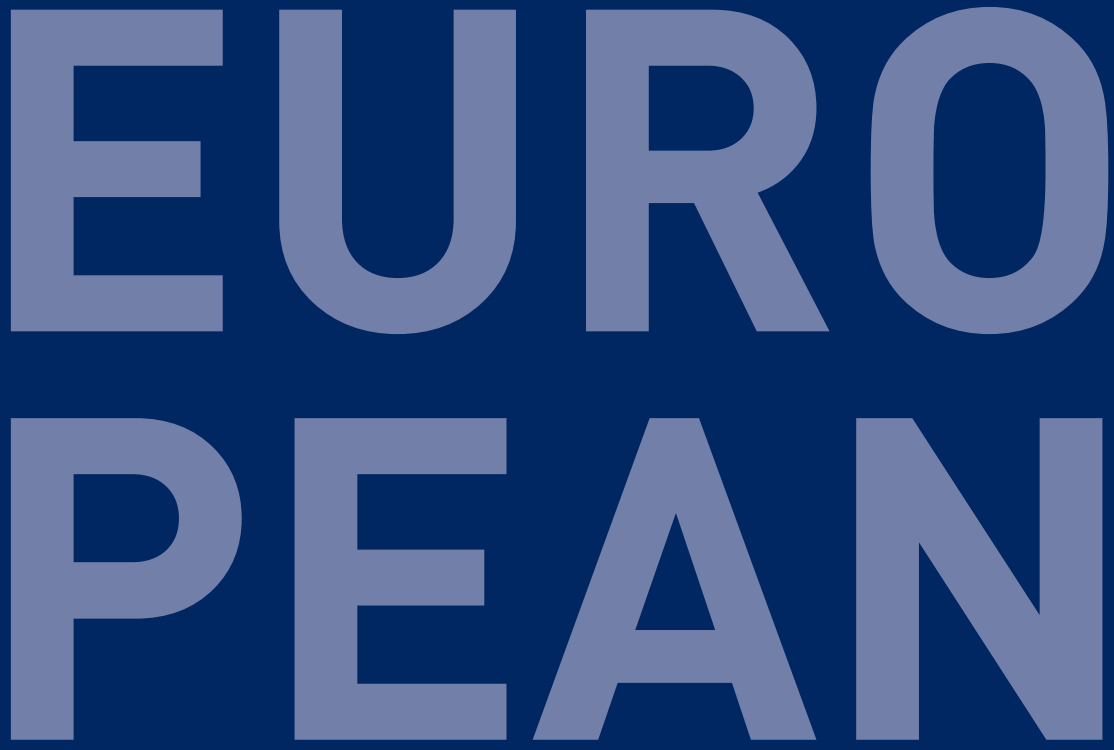

\section{PUBLIC SECTOR ACCOUNTING}

PETER C. LORSON SUSANA JORGE ELLEN HAUSTEIN

(EDS.) 


\title{
CHA P T E R 14 \\ PUBLIC SECTOR ACCOUNTING FUTURE CHALLENGES: EPSASOUTLOOK
}

\author{
Lisa Schmidthuber, Dennis Hilgers \\ Johannes Kepler University Linz, Austria \\ lisa.schmidthuber@jku.at \\ bttps://orcid.org/0000-0002-0349-9965 \\ dennis.hilgers@jku.at \\ bttps://orcid.org/0000-0003-2660-7057
}

\section{SUMMARY}

In March 2013, the EC announced the development of European accounting standards for the public sector. The European Public Sector Accounting Standards (EPSAS) aim to harmonise public sector accounting across and within EU Member States. EPSAS are still in the process of development, they have not been implemented yet and there is no binding decision about their future implementation. In this chapter, the evolution of a European public sector accounting system is described and the emergence of EPSAS are outlined. The benefits and challenges of implementing EPSAS are discussed, and the concept of the current EPSAS draft is compared with the International Public Sector Accounting Standards (IPSAS). Besides, the potential process of implementing EPSAS is described. Finally, future challenges in terms of adopting EPSAS are discussed.

\section{KEYWORDS}

EPSAS, European accounting, accounting harmonisation 


\section{Introduction}

In 2013, the European Commission (EC) announced the development of European accounting standards for the public sector. In this context, the EC authorised Eurostat to provide a review of IPSAS and to elaborate on the suitability of IPSAS for harmonisation of public sector accounting in the EU Member States. However, Eurostat came to the conclusion that IPSAS "cannot easily be implemented in the EU Member States as it stands currently", so that an European set of accounting standards should be developed. The European Public Sector Accounting standards (EPSAS), however, should be based on the IPSAS. ${ }^{1}$ The European standards for use in the public sector are currently developed and are aimed to be adopted in the next years by all government levels and social security funds in EU Member States. Still currently, an impact assessment is being conducted by Eurostat as required by the ECOFIN in November 2017. Thus, whether EPSAS will really come into place is still open, despite the efforts already taken by the EPSAS Task Force of Eurostat. ${ }^{2}$ This chapter gives an overview on the recent developments in terms of European public sector accounting and focuses on the emergence of EPSAS, associated benefits and challenges for EU Member States.

This chapter has the following aims:

- Explaining the evolution of the EPSAS Project and its current (uncompleted) status.

- Describing what are EPSAS, what are the aims of adopting EPSAS and how they would differ from IPSAS.

- Discussing expected benefits and challenges of a potential EPSAS implementation.

- Illustrating the implementation of EPSAS.

- Outlining the next steps towards adopting EPSAS.

\footnotetext{
1 European Commission (2013).

2 European Commission (2017).
} 
The chapter is structured as follows: In Section 2, the evolution of European standards for the public sector is outlined. Section 3 describes the aims, distinguishes the EPSAS from the IPSAS concept, and discusses benefits and challenges of implementing EPSAS. Section 4 focuses on the conceptual framework, the EPSAS framework, and the users of EPSAS. Section $\mathbf{5}$ gives an outlook, and Section $\mathbf{6}$ concludes the chapter.

\section{Evolution of EPSAS}

The need for more comprehensive and transparent reporting of fiscal data and the importance of governments' financial stability have been stressed during the sovereign debt crisis in the years 2008/09 in some of the European Union Member States. In 2011, the so-called Six-pack legislative package was adopted by the EU Council and approved by all 27 Member States and the European Parliament. The package aims to strenghten economic governance in the EU. It encompasses five regulations and one directive. The Budgetary Framework Directive (Council Directive 2011/85/EU) regulates that EU public sector accounting systems should comprehensively and consistently cover all sub-sectors of general government. Next to fiscal discipline ensured by the obligation to avoid excessive government deficits (Article 126 of the Treaty on the Functioning of the European Union (TFEU)), the Directive stresses that financial stability is based on trust. To ensure trust, the fiscal situation should be measured and forecasted in an improved manner. This should be guaranteed by harmonised public sector accrual-based accounting standards.

As the International Public Sector Accounting Standards (IPSAS) have been the only internationally recognised set of public-sector accounting standards in 2011, the EC was instructed to evaluate the suitability of the IPSAS for EU Member States (Article 16(3) of Directive 2011/85/EU) by 31 December 2012. In 2012, the suitability of IPSAS for use in the EU Member States was assessed by a public consultation. Citizens, organisations, national governments and authorities were able to participate. The results of the public consultation show that 38 percent of respondents agreed that 
IPSAS are suitable for their use in the EU, 31 percent partly agreed, and the remaining 31 percent disagreed. ${ }^{3}$ For example, IPSAS were criticised for their incompleteness for use in the public sector. Accordingly, certain public-sector characteristics are not covered by IPSAS (e.g., social benefits, taxation). Furthermore, arguments against IPSAS include their complexity and their link to the International Financial Reporting Standards (IFRS) for use in the private sector.

In March 2013, the EC published its report "Toward implementing harmonised public sector accounting standards in Member States", in which the EU concluded that "IPSAS cannot easily be implemented in EU Member States as it stands currently" "4. Thus, in 2013, the EC decided to develop a separate set of standards, called EPSAS. However, IPSAS should be a suitable reference framework for the development of EPSAS.

As a consequence, the EPSAS Task Force on Governance was created in 2013 to exchange opinions with Member States' authorities about EPSAS governance arrangements and key principles of EPSAS. The Task Force supports Eurostat in developing the EPSAS governance structure.

In 2014, the EPSAS Task Force on Standards was developed in order to exchange about technical aspects of the standards. The Task Force examines the IPSAS and possible problems in practice, discusses how standards can be developed for small public entities also and the implementation of standards via a progressive batched approach ${ }^{5}$.

In March 2015, it was proposed to establish an EPSAS Cell on FirstTime Implementation (FTI) which is responsible for preparing a draft guidance note on First Time Implementation for the opening balance sheet. The cell specifies the level of guidance for the opening balance sheet and works on definitions on relevant basic terms.

Also in 2015, an EPSAS working group has been established as the "first EU network of public sector accounting standard-setters at the core of EPSAS development and implementation". It deals with the introduction, the

\footnotetext{
3 European Commission (2012).

4 European Commission (2013).

5 Ernst \& Young (2017).
} 
development and operation of EPSAS and has invited representatives from all Member States covering all sub-sectors of general government ${ }^{6}$. In 2015, the three "Cells" were instituted: EPSAS Cell First Time Implementation, EPSAS Cell on Governance Principles, EPSAS Cell on Principles related to EPSAS Standards.

Implementing EPSAS requires an EPSAS Governance setting. Figure 14.1 summarizes the current institutions working on the development of EPSAS ${ }^{7}$.

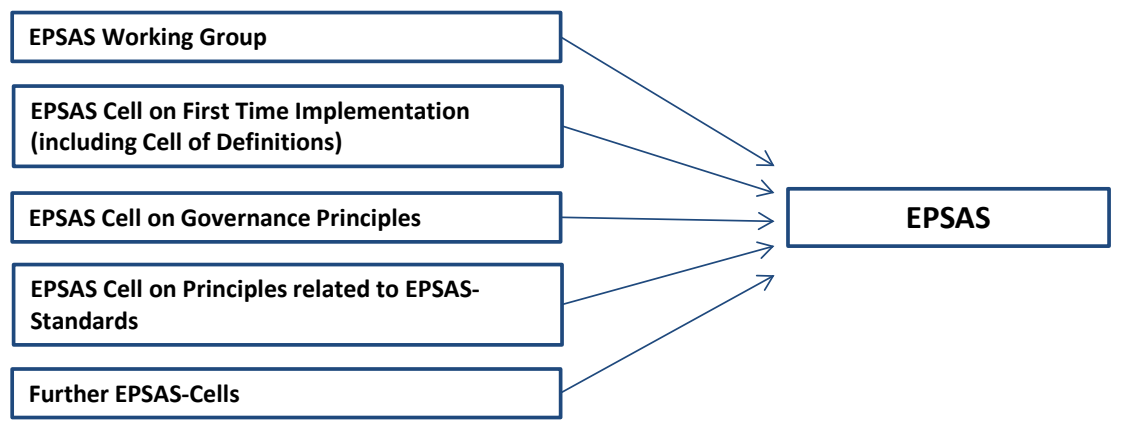

Figure 14.1: EPSAS

Source: Müller-Marqués Berger, 2016, p.2

\section{EPSAS: Background}

\subsection{Aims of EPSAS}

The European Public Sector Accounting Standards, shortly EPSAS, are harmonised public sector accrual-based accounting standards for use in all entities of the government sector.

Need for fiscal transparency: The EPSAS should be accrual-based, as the EC explains that "[a]ccruals accounting is the only generally accepted information system that provides a complete and reliable picture of the

\footnotetext{
6 Makaronidis (2016).

7 Müller-Marques Berger (2016).
} 
financial and economic position and performance of a government" 8 . Assets and liabilities and revenue and expenses of an entity are captured over the period covered by the accounts and at the moment they are closed. The EC favours accruals accounting over cash accounting, as "[a]ccruals accounting is economically sounder than cash accounting". Instead of replacing, accruals accounting should complement cash accounting, according to the EC. ${ }^{9}$

Applying EPSAS is expected to enhance accountability and transparency between and within EU Member States. The complete and comparable reporting of a government's financial position and performance results in more transparent information. This information should be of use for internal decision-makers and users outside government entities. Harmonised accounting practices further enable comparing financial information over time, between EU Member States and across individual entities, so that accountability of public activities can be increased ${ }^{10}$.

Need for comparability: Harmonised European public sector accounting means that a single-set of accrual-based accounting standards should be used at all levels of government throughout the EU. The harmonisation should improve the effectiveness and efficiency of public administration. Furthermore, liquidity of governments should be ensured. Finally, accounting harmonisation enhances transparency, accountability, and the comparability of financial reporting in the public sector, and thus also faciliates public audit. ${ }^{11}$

Implementing EPSAS should also be associated with better decision making. Accrual-based financial information offers more detailed data on administrative processes and government performance. Complete and comparable information is necessary as a basis for decision making and future planning. Accordingly, public managers and politicians can use

\footnotetext{
8 Please see Chapters 4 and 5 for details.

9 European Commission (2013), p.3.

10 PwC (2014); Aggestam-Pontoppidan and Brusca (2016); Brusca and Martínez (2016); Christians et al. (2015).

11 European Commission (2013); Makaronidis (2016).
} 
EPSAS-based financial information for deciding about how to allocate financial resources. ${ }^{12}$

Finally, the incoherence between micro-level and the European System of Accounts (ESA) macro-level accounting and reporting frameworks should be minimised. Due to the fact that many public sector accounts record only cash flows and the EU budgetary surveillance is based on ESA 95 accruals data, cash data has to be transferred to accruals. ${ }^{13}$

\subsection{IPSAS versus EPSAS}

As already outlined, EPSAS should be based on IPSAS. However, what is the difference between IPSAS and EPSAS? First, IPSAS as the International Public Sector Accounting Standards are the main existing set of international accounting standards for use in the public sector. For a detailed description of IPSAS and an overview on who is developing and using the standards, please see Chapter 7.

Second, EPSAS, as the future European Public Sector Accounting Standards, should be derived to some extent from IPSAS. EPSAS are expected to harmonise public sector accounting in EU Member States. In developing the accounting standards, the experiences and opinions of EU Member States should be integrated.

In sum, whereas some countries align their accounting practices to IPSAS, EU Member States will not fully adopt IPSAS. In terms of EPSAS, IPSAS are seen as a suitable starting point and used as a basis for standard development.

Müller-Marqués Berger and Heiling proposed a way about how to decide to which degree IPSAS should be used as a basis for EPSAS. Figure 14.2 illustrates the process. First, it is asked whether there is an EU-specific reason for deviating from the IPSAS, or, if it is necessary to develop a new

\footnotetext{
12 PwC (2014).

13 European Commission (2013); Makaronidis (2016).
} 
standard. Second, it must be decided if there is an EPSAS accounting reason justifying a deviation from the ESA 2010.

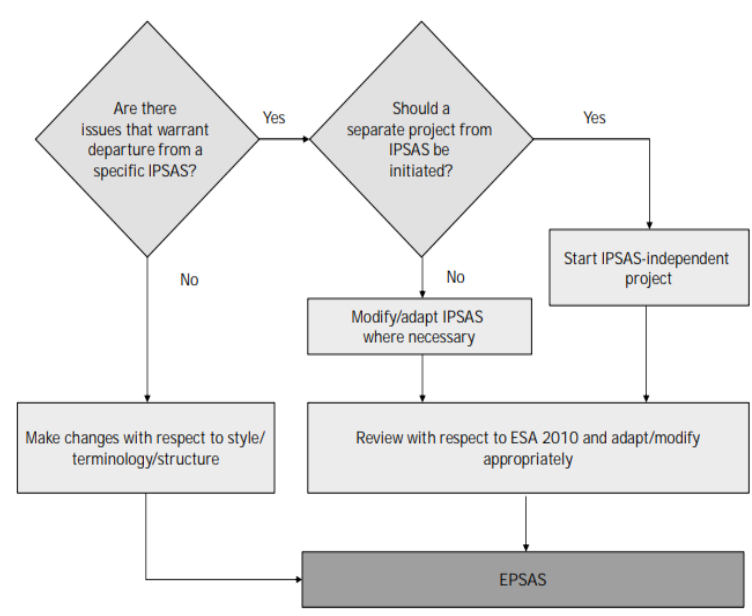

Figure 14.2: "EPSAS Rules of the Road"-Standard adaption Source: Müller-Marqués Berger E Heiling (2015) p.10.

\subsection{Implementing EPSAS: Reasons, impacts, and challenges}

The introduction of EPSAS is discussed highly controversially. Supporters of EPSAS reason the need for a harmonised European accounting system, as follows: ${ }^{14}$

- Current accounting systems are criticised by their inaccuracy, which might lead to ill-founded policy decisions.

- Insufficient consolidation efforts result in underestimated deficits and debts.

- There are no EU standards that regulate how individual transactions and events should be recorded, recognised, measured, consolidated, and reported.

14 European Council (2013); Makaronidis (2016), p.5. 
- Data of governments of EU Member States lack comparability and transparency.

- Comparison is insufficient in terms of economic governance, internal markets, and statistics.

- A lack of European government sector accounting harmonisation might result in hampered efficiency and effectiveness, limited accountability, reduced access to financial markets, and challenges for public auditors on the national and entity level.

The introduction of EPSAS aims at addressing these current challenges and creating benefits for the EU and Member States alike. In conclusion, Table 14.1 gives an overview on the expected benefits and impacts of EPSAS introduction for the main stakeholders:

\begin{tabular}{|c|c|}
\hline Stakeholder Group & Expected benefits and impacts \\
\hline Preparers & $\begin{array}{l}\text { - Use of accrual-based concepts in daily work } \\
\text { - Increase in qualifications and skills }\end{array}$ \\
\hline Auditors & $\begin{array}{l}\text { - Harmonisation of policies across governments leads to } \\
\text { greater standardisation in audit methodology. } \\
\text { - High-quality information from reporting entities. }\end{array}$ \\
\hline Internal users & $\begin{array}{l}\text { - Ability to use high-quality information for performance } \\
\text { evaluation and decision-making. } \\
\text { - Long-term impacts of current decisions are reflected in } \\
\text { financial statements so that intergenerational fairness } \\
\text { could be achieved. }\end{array}$ \\
\hline External users & $\begin{array}{l}\text { - Transparent and comparable information for stakeholders } \\
\text { in financial markets, politicians and citizens. } \\
\text { - Due to complexity of accrual accounting, ability to } \\
\text { interpret numbers and figures is necessary. Thus, the } \\
\text { media has an important role to spread financial } \\
\text { information towards the general public. }\end{array}$ \\
\hline
\end{tabular}

Table 14.1: Expected Impacts of EPSAS Implementation for Stakebolder Groups Source: PwC (2014) pp.141f. 
Adopting EPSAS means changing the current accounting regime and implementing new accounting standards. ${ }^{15}$ This reform process is contingent on expenses. The level of costs depends on the accounting maturity of the institutions. Accordingly, the more the government's accounting rules comply with an IPSAS-based benchmark and the higher the accounting maturity, the lower the costs for switching to EPSAS will be. Besides, if accounting maturity varies between or within different government levels, government complexity and thus expected reform costs increase. In addition, the reform costs depend on the government size. The number of processed transactions, amount of data and number of employees increase by government size, so that the reform process is more expensive in large governments. For example, the more employees need training on new accounting procedures and policies, the higher the training costs. Finally, adopting EPSAS needs IT investments capable for accrual-based accounting. Accordingly, the reform costs depend on the IT maturity of the institution. If just adaptions of the current IT system are needed, the costs are lower than if a severe IT system reform for all entities is needed due to low IT maturity. For example, in terms of Austria, the best-case scenario involves costs of about $€ 40$ million, the worst-case scenario costs of approximately $€ 243$ million. Consequently, IT investments are a serious cost driver of adopting EPSAS. ${ }^{16}$ However, a high quality IT system improves the effectiveness of control and administrative processes. Increasing efficiency might reduce administrative costs for implementing new IT infrastructure.

"First-Time Adoption Dilemma": The First-Time Adoption of EPSAS can be seen as a dilemma, as (1) assets and liabilities of an entity have to be assessed completely, (2) the most accurate measurement should be used, and (3) there are several restricting factors in terms of time and resources. Due to these problems, it is recommended to restrict the completeness requirement to the most significant assets and liabilities. Furthermore, it is necessary to provide simplification in terms of measurement requirements for selected items and develop concrete guidelines for the preparation of the

\footnotetext{
15 See Hessisches Ministerium der Finanzen (w.y.).

16 PwC (2014).
} 
EPSAS opening balance sheet. Finally, a standard on first-time adoption of EPSAS with detailed instructions and instruments is recommended ${ }^{17}$.

First studies discuss the challenges of transitioning an accrual-baed to a European-harmonised public accounting system ${ }^{18}$. Challenges of implementing EPSAS can be discussed, structured by the following dimensions: ${ }^{19}$

- Policies: Adopting EPSAS means adapting existing financial rules and regulations and document accounting policies. Furthermore, a comprehensive guidance and manuals as well as concise implementation rules have to be developed for the most complex topics.

- Processes: In terms of processes, the transition period has to be managed and the implementation phase has to be monitored. Data quality has to be monitored during the reform process, so that quality control procedures have to be implemented. Data collection procedures have to be set up (e.g. for fixed assets). In addition, compliance with existing regulatory framework has to be ensured.

- Systems: The EPSAS reform requires an adaption of existing IT systems and a development of new IT solutions/modules. Furthermore, organisational processes have to be adapted to the IT environment.

- People: Next to IT systems, human resources are essential in terms of the accounting reform. The change of accounting practices requires training programmes for employees and the help of external consultancy. Furthermore, organisational culture must be open for change and political support and commitment is necessary to be successful in the reform process.

\section{Conceptual Framework}

The conceptual framework (EPSAS CF) encompasses " $a$ set of concepts and definitions for the development, the adoption, and the publication of

\footnotetext{
17 Müller-Marqués Berger and Heiling (2015), p.10.

18 E.g. Hessisches Ministerium der Finanzen (w.y.).

19 PwC (2014).
} 
EPSAS and provides guidance for the preparation and the presentation of financial accounting information by public sector entities under the EPSAS basis of accounting". ${ }^{20}$ Furthermore, the EPSAS CF should help users interpreting financial information. ${ }^{21}$ The EPSAS Conceptual Framework is required to be developed before the EPSAS standards are introduced.

The EPSAS CF aims at ensuring consistency between the EPSAS and also should support in presenting relevant events and transactions, when guidance is needed due to different interpretations or the lack of a specific standard. The framework should guide public sector reporting entities at all government levels, social security funds and other reporting entities adopting EPSAS as basis of accounting ${ }^{22}$. EPSAS are expected to be applied by public entities belonging to the general government sector.

\section{Outlook}

Figure 14.3 summarises the timeline for implementing EPSAS. The implementation of accrual-based accounting (highlighted in white) is distinguished from the development and legal endorsement of EPSAS (highlighted in grey). During the first stage of five years, the EC encourages the voluntary introduction of accrual accounting by providing financial support. Furthermore, the conceptual framework should be completed regarding the cells on EPSAS governance principles and principles related to EPSAS standards. EPSAS standards should be prepared, and the consolidation of whole of government accounts should be achieved. Finally, the EPSAS framework and standards should be adopted. In the second stage, EPSAS should be gradually implemented by all public entities of EU Member States. Whereas the first stage is supposed to increase financial transparency in the EU Member States, the second stage should improve comparability. ${ }^{23}$

\footnotetext{
20 European Commission (2018), p. 4.

21 The aims of a conceptual framework are described in detail in Chapter 8 .

22 European Commission (2018).

23 European Commission (2016).
} 


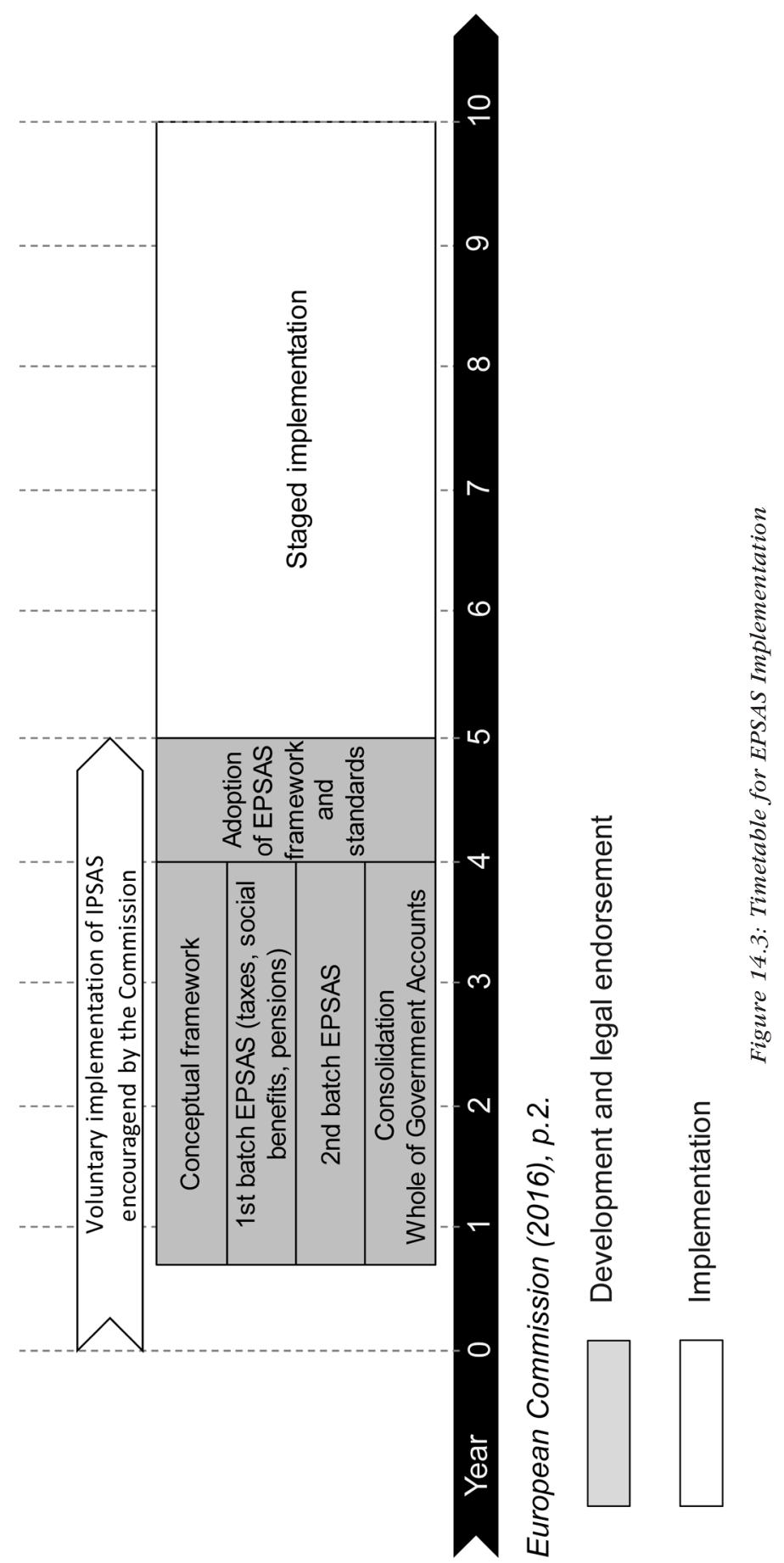




\section{Conclusion}

EPSAS as the European Public Sector Accounting Standards are accrualbased accounting standards currently being developed for public entities belonging to the general government. Instead of fully applying IPSAS in Europe, the International Public Sector Accounting Standards and the IPSAS $\mathrm{CF}$ are used as a basis for EPSAS standard development. In this process of implementing public sector accounting standards for EU Member States, however, it has to be determined to what extent EPSAS can be derived from IPSAS and to what extent EPSAS have to be newly developed. Although some IPSAS standards might be of use for EPSAS development, IPSASbased accounting standards have to be complemented with corresponding budgeting standards, as IPSAS has not taken budgeting into account. In this regard, rules of consolidation have to be developed in line with a new accounting system, and the design of the IPSAS-based endorsement process has to be adapted. Finally, the costs associated with implementing EPSAS and the related benefits have to be analysed.

For those EU Member States having refused to implement IPSAS so far, applying EPSAS is related to enormous application and switching costs and efforts. A successful implementation of EPSAS means adapting the national budget law and empowering European budget monitoring.

\section{Bibliographic references}

BRUSCA, Isabel and MARTINEZ, Juan Carlos (2016) - Adopting international public sector accounting standards: A challenge for modernizing and harmonizing public sector accounting. International Review of Administrative Sciences, 82(4), 724-744.

CHRISTIAENS, Johan, VANHEE, Christophe, MANES-ROSSI, Francesca, AVERSANO, Natalia and VAN CAUWENBERGE, Philippe (2015) - The effect of IPSAS on reforming governmental financial reporting: An international comparison. International Review of Administrative Sciences, 81(1), 158-177.

ERNST \& YOUNG (2017) - Steps taken by the European Commission. Retrieved from: http:// www.ey.com/be/en/issues/ifrs/ipsas-epsas/ipsas-epsas_steps-taken (12.02.2019).

EUROPEAN COMMISSION (2012) - Public consultation - Assessment of the suitability of the International Public Sector Accounting Standards for the Member States. Summary of Responses. Luxembourg. 
EUROPEAN COMMISSION (2013) - Report from the Commission to the Council and the European Parliament. Towards implementing harmonised public sector accounting standards in Member States. The suitability of IPSAS for the Member states. Brussels, March 2013. https://eur-lex.europa.eu/legal-content/EN/TXT/PDF/?uri=CELEX:52013D C0114\&from=en (accessed 18/02/2019).

EUROPEAN COMMISSION (2016) - Next steps 2017. 3rd meeting of the EPSAS Working Group. Rome.

EUROPEAN COMMISSION (2017) - EPSAS impact assessment consideration. https://circabc. europa.eu/sd/a/919e4d5e-f567-4122-9225-4deecf069f90/Item\%204\%20-\%20EPSAS\%20 Impact\%20considerations.pdf (accessed 13/05/2019).

EUROPEAN COMMISSION (2018) - European Public Sector Accounting Standards - Conceptual Framework. Reflection paper - for discussion. April 2018. EPSAS WG 18/07.

EUROPEAN COUNCIL (2013) - Strengthening public sector accounting for sound fiscal policies in Europe. Keynote speech at the Conference "Towards Implementing European Public Sector Accounting Standards. Brussels. https://ec.europa.eu/eurostat/ documents/1001617/1012817/speech-Pres-Van-Rompuy-290513.pdf (accessed 19/02/2019).

HESSISCHES MINISTERIUM DER FINANZEN (w.y.) - Studie zur Umstellung eines doppischen Rechnungswesens auf einheitliche europäische Rechnungslegungsstandards am Beispiel des Bundeslandes Hessen. https://finanzen.hessen.de/sites/default/files/media/hmdf/ studie_-_umstellung_zu_epsas.pdf (accessed 31/05/2019). [in German only]

MAKARONIDIS, Alexandre (2016) - EY Seminar on EPSAS. EPSAS - current status and latest developments. Brussels. https://www.ey.com/Publication/vwLUAssets/EPSAS_current_ status_and_latest_developments/\$FILE/3_EPSAS\%20EY\%2013\%20MAY\%202016\%20vD. pdf (accessed 13/02/2019).

MÜLLER-MARQUÉS BERGER, Thomas (2016) - Cell on First-time Implementation. Seminar on Accounting reforms in the Public Sector IPSAS/EPSAS. Brussels. Retrieved from: http://www.ey.com/Publication/vwLUAssets/Cell_on_Firsttime_Implementation/\$FILE/4_ Cell\%20on\%20First-time\%20Implementation_EY_final.pdf (05.02.2019)

MÜLLER-MARQUÉS BERGER, Thomas and HEILING, Jens (2015) - European accounting standards for the public sector. What contribution can the International Public Sector Accounting Standards (IPSAS) make? https://www.ey.com/Publication/vwLUAssets/ european-accounting-standards-for-the-public-sector/\$FILE/European-accounting-standardsfor-the-public-sector.pdf (accessed 03/01/2019).

PONTOPPIDAN, Caroline Aggestam and BRUSCA, Isabel (2016) - The first steps towards harmonizing public sector accounting for European Union member states: strategies and perspectives. Public Money \& Management, 36(3), 181-188.

PWC (2014) - Collection of information related to the potential impact, including costs, of implementing accrual accounting in the public sector and technical analysis of the suitability of individual IPSAS standards. https://ec.europa.eu/eurostat/ documents/1015035/4261806/EPSAS-study-final-PwC-report.pdf (accessed 13/02/2019).

\section{Additional readings}

BRUSCA, Isabel (2016) - Harmonizing public sector accounting in Europe: thinking out of the box. Public Money \& Management, 36(3), 189-196.

BRUSCA, Isabel; CAPERCHIONE, Eugenio; COHEN, Sandra and MANES-ROSSI, Francesca (2018) - IPSAS, EPSAS and other challenges in European public sector accounting and auditing. In The Palgrave Handbook of Public Administration and Management in Europe (pp. 165-185). Palgrave Macmillan, London. 
BURTH, A. and HILGERS, D. (2019) - Towards harmonised European Public Sector Accounting Standards. https://www.epsas.eu/en/

JONES, Rowan and CARUANA, Josette (2015) - EPSAS-Worrying the Wrong End of the Stick?. International Journal of Public Administration, 38(4), 240-252.

MANES ROSSI, Francesca; CAPERCHIONE, Eugenio; COHEN, Sandra, and

OULASVIRTA, L. O., \& BAILEY, S. J. (2016) - Evolution of EU public sector financial accounting standardisation: critical events that opened the window for attempted policy change. Journal of European Integration, 38(6), 653-669.

\section{Discussion topics}

- Does adopting EPSAS provide more benefits than using national standards or IPSAS?

- What are the differences between IPSAS and EPSAS?

- What are possible challenges in developing EPSAS?

- What are possible challenges in adopting EPSAS for governments? 